\title{
The importance of considering small-scale variability in macrobenthic distribution: spatial segregation between two fiddler crab species (genus Leptuca) (Decapoda, Ocypodidae)
}

\author{
Helio H. Checon ${ }^{1,2}$ (1) \& Tânia M. Costa ${ }^{3}$ (iD
}

\begin{abstract}
1. Departamento de Biologia Animal, Universidade Estadual de Campinas, Rua Monteiro Lobato, 255, 13083-862 Campinas, SP, Brazil.
2.Departamento de Oceanografia Biológica, Instituto Oceanográfico, Universidade de São Paulo, Praça do Oceanográfico, 191, 05508-120 São Paulo, SP, Brazil. (hchecon@yahoo.com.br)

3.Laboratório de Ecologia e Comportamento Animal, Instituto de Biociências, Universidade Estadual Paulista - UNESP, Campus Litoral, Praça Infante Dom Henrique, s/n, Caixa Postal 73610, 11380-972, São Vicente, SP, Brazil. (tania.costa@unesp.br)
\end{abstract}

Received 10 July 2017

Accepted 20 August 2018

Published 29 November 2018

DOI 10.1590/1678-4766e2018034

\begin{abstract}
Defining the appropriate scale is important when trying to understand distribution patterns in community studies. Fiddler crabs are among the most common organisms inhabiting estuarine environments, and despite having a wide latitudinal distribution, are limited by shifts in temperature, current and wind pattern. Thus, many co-occur at a local scale, where their distribution is influenced by variables such as mean sediment grain diameter, salinity and tidal level. Our goal was to test intra and interspecific segregation in two similar and commonly co-occurring fiddler crabs species (Leptuca leptodactyla and Leptuca uruguayensis) at a small scale $\left(10 \mathrm{~m}^{2}\right)$. Interspecific segregation was observed, with L. leptodactyla occurring mainly at the upper level in relation to the water line and L. uruguayensis, at the lower. However, this pattern was irrespective of sex and developmental stage, as no intraspecific segregation was seen. Possible impacts of tidal level, soil silt/clay content and competition on interspecific segregation are discussed. Although L. leptodactyla and L. uruguayensis overlap in their occurrence when intertidal zonation is disregarded, they segregate when tidal levels are individually sampled as habitats. This highlights the importance of small-scale studies to identify patterns unobserved at regional scales, even when no environmental gradient is readily apparent.
\end{abstract}

KEYWORDS. Fiddler crabs, estuarine beach, small-scale, Leptuca, allometric growth.

RESUMO. A importância de considerar a variabilidade em pequena escala na distribuição macrobêntica: segregação espacial entre duas espécies de caranguejo chama-maré (gênero Leptuca) (Decapoda, Ocypodidae). Definir a escala apropriada de um estudo é importante quando tentamos entender os padrões de distribuição em estudos de comunidade. Caranguejos chama-maré estão entre os organismos mais comuns que habitam os ambientes estuarinos, e apesar de possuírem uma ampla distribuição latitudinal, são limitados por alterações em temperatura, correntes e padrões dos ventos. Dessa forma, muitas espécies co-ocorrem em escala local, onde suas distribuições são influenciadas por variáveis como diâmetro do grão de sedimento, salinidade e nível de maré. Nosso objetivo foi testar a segregação intra- e interespecífica em duas espécies similares de caranguejos chamamaré, que comumente são encontradas em co-ocorrência (Leptuca leptodactyla e Leptuca uruguayensis), em uma pequena escala (10 $\left.\mathrm{m}^{2}\right)$. Foi observada segregação interespecífica, com L. leptodactyla ocorrendo primariamente no nível superior em relação à linha de maré, e L. uruguayensis no inferior. Entretanto, esse padrão foi independente de gênero e estágio de desenvolvimento, uma vez que segregações intraespecíficas não foram registradas. Possíveis influências do nível de maré, teor de silte/argila e competição na segregação interespecífica são discutidas. Apesar de L. leptodactyla e L. uruguayensis terem sobreposição em ocorrência quando a zonação do entremarés é desconsiderada, elas segregam quando os níveis de maré são individualmente amostrados. Esse resultado destaca a importância de estudos em pequena escala para identificar padrões não observados em escala regional, mesmo quando nenhum gradiente ambiental é inicialmente observado.

PALAVRAS-CHAVE. Caranguejos chama-maré, praia estuarina, pequena escala, Leptuca, crescimento alométrico.

The spatial arrangement of species is a common subject of ecological studies, and different distribution patterns have been described (e.g. aggregated, random) (THrush et al., 1989; GreEn \& PlotKIn, 2007). Analysis of these spatial patterns on community studies reveals how species co-occur in a given habitat, and whether they overlap or segregate (Gotelli \& McCabe, 2002; Horner-Devine et al., 2007). Patterns observed at a restricted location may not be the same if we increase or decrease the scale of observation. Scaling influences the perception of how species explore and/or share resource and habitat (WIENS, 1989; LEVIN, 1992; Alves et al., 2013). Sex, age or body-size classes of species that co-occur at large scales may be locally segregated by changes on conditions or resources availability (MURAI et al., 1983; Baltz \& Moyle, 1984; Thrush et al., 1996; Alves et al., 2013). Local segregation may be seen in both intra and interspecific relationships. The recognition of patterns and processes observed at a small scale are important to fully understand species distribution, as well as for maintaining diversity across scales (Levin, 1992; HewitT et al., 2005). 
Fiddler crabs are among the most abundant benthic macrofauna representatives inhabiting estuarine environments. All fiddler crabs have until recently been considered to be in a unique genus (Uca Leach, 1814), composed of 97 widely distributed species (CRANE, 1975; RosenBerg, 2001), but current reorganization has separated them into different genera based on phylogenetic relationships(SHIH et al., 2016). Although each species shows a varied distribution range, in many areas theses ranges overlap and co-occurrence is common (CRANE, 1975; NABOUT et al., 2009; THURMAN et al., 2013). Factors affecting large-scales patterns are related to larval survival during dispersal and settlement, such as water current, wind pattern and temperature change with latitudinal gradients (BogAZZI et al., 2001; NABOUT et al., 2009; WiEMAN et al., 2014). On a local scale, variables such as sediment grain size, tidal level, vegetation cover and salinity influence species occurrence and distribution (THURMAN, 1987; Thurman et al., 2013; Mohktari et al., 2015; CheCon \& CosTA, 2017). Therefore, this suggests that the patterns observed for large scales may differ from local ones.

The Brazilian coast boasts one of the largest mangrove areas in the world, housing ten fiddler crab species in native mangroves and estuaries (THURMAN et al., 2013), with Leptuca leptodactyla (Rathbun in Rankin, 1898) (Ocypodidae) and Leptuca uruguayensis (Nobili, 1901) (Ocypodidae) being among the most common ones on the Southeastern coast. These are visually similar and present equivalent mean carapace width, and although males exhibit different colors and chela morphology, females may be easily misclassified (Melo, 1996). Leptuca consists of small sized, broad-front American species, presenting moderate to numerous spoontipped setae and one third of the pleon segments partially or completely fused (BEZERRA, 2012). They are usually found co-occurring in estuarine environments, but at large scales their distribution differs.

Leptuca leptodactyla have a wide distribution range, from Caribe $\left(\sim 25^{\circ} 01^{\prime} \mathrm{N} ; 77^{\circ} 23^{\prime} \mathrm{W}\right)$ to southern Brazil ( $27^{\circ} 38^{\prime} \mathrm{S}$; 48 40'W) (Melo, 1996; Thurman et al., 2013), whereas L. uruguayensis ranges from southeastern

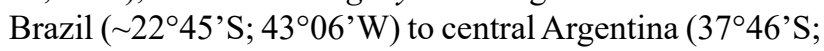
$57^{\circ} 27^{\prime} \mathrm{W}$ ) (SPIVAK et al., 1991; ThURMan et al., 2013). Thus, these co-occur over a short range, from southeastern to southern Brazil. Locally, L. leptodactyla seem more restricted, inhabiting locations with absence of vegetation and sandy sediments (CHECON \& COSTA, 2017). In turn, L. uruguayensis have a more generalist behavior, irrespective of vegetation presence, with both species co-occuring in unvegetated areas with low content of mud and very fine sands, known to burrow on similar sediment type (THURMAN et al., 2013; CHECON \& Costa, 2017). They also share similarities regarding internal burrow morphology and bioturbation activity (MACHADO et al., 2013; NatAlio et al., 2017).

Given the importance of how the scale might affect species distribution, our aim was to investigate whether two co-occuring fiddler crab species (L. leptodactyla and $L$. uruguayensis) segregate intra or interspecifically in relation to changes in local tide level at a small-scale. We focused on identifying segregation patterns at a $10 \mathrm{~m}^{2}$ scale within an estuarine environment. Our first hypothesis is that species would exhibit segregation at a small-scale variation, due to variations related to tide level. Our second hypothesis is that these variations related to tide level could cause ontogenetic segregation could occur between juveniles and adults, as has been reported for other fiddler crabs, which could be caused by ontogenetic niche shifts (i.e. changes in niche requirements with developmental stage) (WerNer \& GilLIAM, 1984).

\section{MATERIAL AND METHODS}

Study area and sampling design. This study was carried out at a fragmented area on the estuarine system of Mar Pequeno (2359'S; 46²4'W), southern Brazil. This estuary is known as Manguezal do Portinho and is composed of isolated mangrove fragments with distinct features in regards to sediment composition, brackish water input and presence of vegetation.

To test the hypothesis that small-scale segregation would be found in regards to tide level, we chose an area where L. leptodactyla and L. uruguayensis could co-occur. Thus, the study was carried out at a small estuarine beach, with absence of vegetation cover and predominance of sandy sediment fractions. The area $\left(10 \mathrm{~m}^{2}\right)$ was located at a river margin, close to the mouth that flows into the estuary. Presence of the target species was previously recorded in the area. No other species occurred there, although Leptuca thayeri (Rathbun, 1900) and Uca maracoani (Latreille, 1802) were found at nearby muddy banks.

The area was divided into two subareas to check for small-scale segregation in regards to tide variation. Subareas were determined based on tidal level. Subarea A was located on the upper level of the intertidal area, being submerged only during spring flood tides, whereas subarea B was located on the lower level of the intertidal area, being completely submerged during neap flood tides (Fig. 1).

Sampling took place monthly during a one-year period (Feb/2008-Jan/2009), at low tide and under sunny conditions. Quadrat samples with an area of $0.25 \mathrm{~m}^{2}$ were used as sampling units. Similar sized quadrats have been employed in other studies with L. leptodactyla and L. uruguayensis (SPivaK et al., 1991; Bezerra et al., 2006; CARDoso, 2007). Six randomly placed replicates were sampled in each subarea (Fig. 1). For each replicate, crab burrows were recorded and individuals were taken from their burrows using a modified garden shovel and stored in plastic pots. Crabs were later identified, sexed and measured. Males had carapace width (CW) and propodus length (PL) measured, whereas females had carapace width $(\mathrm{CW})$ and abdomen width (AW) measured. Due to similarity between species, very small individuals $(<4 \mathrm{~mm}$ ) could not be confidently identified and were not considered to reduce bias. Sampled individuals were returned to the area, but only after sampling procedures were finished so to avoid recapture.

Subareas were characterized in regards to granulometric composition and organic matter content. Three 


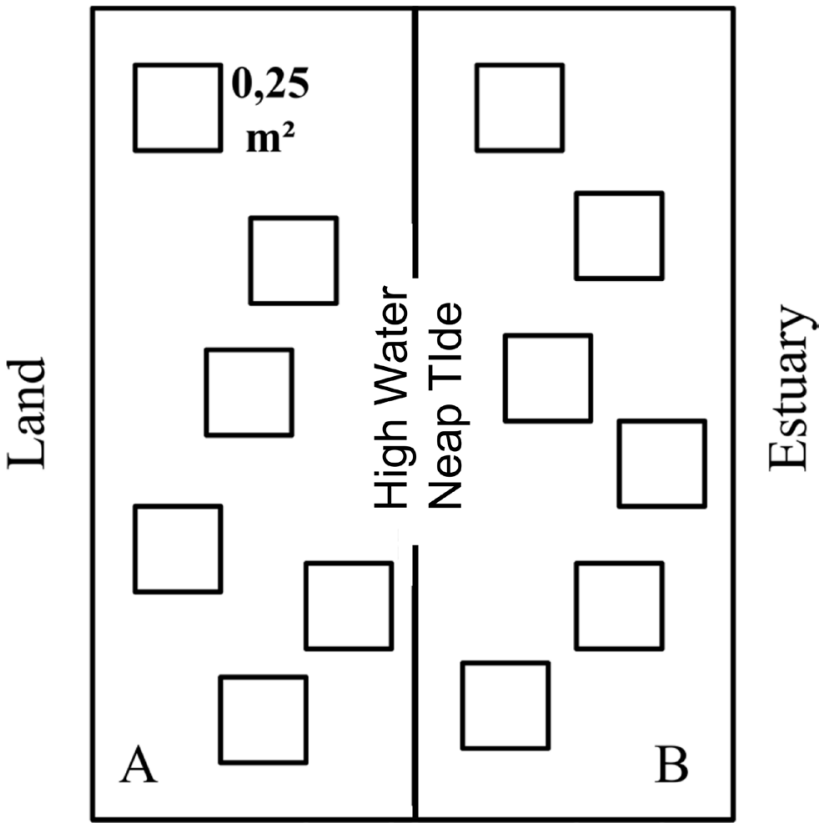

Fig. 1. Schematic representation of the sampling design, with subarea separation and the six random replicates. (Area $=10 \mathrm{~m}^{2}$ ).

sediment samples were taken using a $10 \mathrm{~cm}$ corer, $10 \mathrm{~cm}$ deep, from each subarea to evaluate these variables. Organic matter content was assessed by the weight difference between dried and muffle-heated samples $\left(300^{\circ} \mathrm{C}\right.$ for three hours). Granulometric composition was evaluated by sieving samples in seven granulometric fractions. Sediment classification and mean grain diameter were calculated using appropriate methodology (FoLK \& WARD, 1957).

Data analysis. In order to classify individuals as juveniles or adults, size at onset of sexual maturity was determined using allometric growth analysis (HARTNOLL, 1978), which has been previously applied in fiddler crab studies (Masunari \& Swiech-Ayoub, 2003; NegreirosFransozo et al., 2003; Hirose et al., 2013). This procedure was executed separately for both males and females of the two species. The relationships were: CW x PL for males and $\mathrm{CW} \times \mathrm{AW}$ for females. The power function $\mathrm{Y}=\mathrm{a} \mathrm{X}^{\mathrm{b}}$ was estimated from the relationship data points and linearized using $\operatorname{LnY}=\operatorname{Lna}+b \operatorname{LnX}$. The allometric constant $b$ is used to characterize growth as positive $(b>1)$, negative $(b<1)$ or isometric $(b=1)$. To determine the size at onset of sexual maturity, we used K-means clustering to distribute the data points into two groups, juveniles and adults. K-means uses an iterative process to separate data points into a pre-defined number of groups (clusters), aiming to minimize the variance of within group data points (JAIN, 2010; HIROSE et al., 2013). The groups defined by k-means were further refined using a linear discriminant analysis (LDA). The size at onset of sexual maturity was defined, via logistic adjustment, as the size where $50 \%$ of the individuals were grouped as adults (SAMPEDRO et al., 1999).

Based on these analyses, eight groups were created to analyze spatial segregation in a combination of species, developmental stage and sex. We employed acronyms to identify these groups. For L. leptodactyla, the four groups were: JLM (juvenile males), JLF (juvenile females), ALM (adult males) and ALF (adult females). Similarly, for $L$. uruguayensis, the groups were: JUM (juvenile males), JUF (juvenile females), AUM (adult males) and AUF (adult females).

To test whether density of each group varied between subareas, a generalized linear model (GLM) was applied. The Poisson distribution was chosen as it is appropriate for dealing with count data (individuals/area) (O'HARA \& Kotze, 2010). The model was checked for overdispersion (residual variance $>>$ residual degrees of freedom), using the function dispersiontest provided in the R package AER (KLeIber \& ZeILeIS, 2008), and when detected, a quasiPoisson distribution model was applied (Ver HoEF \& Boveng, 2007). Time (monthly sampling) was included in the model to verify the influence of temporal variation on the difference between subareas. To account for the differences on the number of individuals on each sample, we used the total density of individuals as an offset term. Significance of each term in the model tested with a chi-square test, for models using Poisson distribution, and with a F-test, for overdispersed models using quasi-poisson distribution (KLEIBER \& ZeILeIS, 2008).

Species distribution among sites was represented on a multivariate space with non-metric multidimensional scaling (NMDS, KRUSKAL, 1964). We used stress $<0.2$ as a suitable limit for a good representation of the results in the multivariate space (CLARKE, 1993). We performed a multivariate permutational analysis (PERMANOVA) (ANDERSON, 2001) to test whether the composition of species group (by sex and developmental stage) in regards to subareas (tide level). Community distance matrix was calculated using Bray-Curtis distance (BRAY \& CURTIS, 1957), which is appropriate to deal with community data (FAITH et al., 1987; Clarke et al., 2006). A t-test was applied to verify differences on organic matter content between subareas. Normality and variance homogeneity were checked using the quantiles plot (q-q plot) and residuals plot (BORCARD et al., 2011). Sediment type was qualitatively compared between areas using the nominal classification defined by the mean grain diameter (e.g. fine sands, very fine sands).

All statistical analyses were executed using R 3.0.2 (R CORE TEAm, 2013). The additional package vegan (OKSANEN et al., 2013) was employed in the multivariate analysis, as well as the AER (KLEIBER \& ZeILEIS, 2008) package to check for overdispersion on GLMs.

\section{RESULTS}

A total of 1,077 crabs of both species were sampled throughout the study. Leptuca leptodactyla had a higher apparent abundance (595 individuals) than L. uruguayensis (482 individuals). Concerning only species, spatial segregation was found, with $L$. leptodactyla occupying more frequently the upper level $\left(\mathrm{F}_{1,143}=190.651, \mathrm{p}<0.001\right)$, and $L$. 
uruguayensis, the lower level $\left(\mathrm{F}_{1,143}=162.272, \mathrm{p}<0.001\right)$ in relation to the water line. This pattern was consistent through sampling periods for both L. leptodactyla $\left(\mathrm{F}_{11,120}=0.810\right.$, $\mathrm{p}=0.630)$ and L. uruguayensis $\left(\mathrm{F}_{11,120}=0.691, \mathrm{p}=0.745\right)$.

Sediment characterization showed the subareas were of a similar granulometric composition and category, with both classified as very fine sands. However, subarea A $(17.94 \pm 5.68 \%)$ had lower silt/clay content than subarea B $(32.03 \pm 11.01 \%)$. Similarly, organic matter content was also not different between subareas, being $2.37 \pm 0.35 \%$ in subarea $A$ and $2.88 \pm 1.04 \%$ in subarea $B(t=-1.155, d f=6, p=0.291)$.

Crab size (CW) was similar in both species and sexes. Leptuca leptodactyla size ranged from 4.3 to 13.4 $\mathrm{mm}$ in males $(8.76 \pm 1.64)$, and 4.1 to $11.4 \mathrm{~mm}$ in females $(8.25 \pm 1.71)$; L. uruguayensis size ranged from 4 to 12.5 $\mathrm{mm}$ in males $(7.9 \pm 1.38)$, and 4 to $10.5 \mathrm{~mm}(7.66 \pm 1.34)$ in females. Size at onset of sexual maturity was determined to be $6.7 \mathrm{~mm}$ in females of both species, and 7.3 and 7.6 $\mathrm{mm}$ in males of L. leptodactyla and L. uruguayensis, respectively. Both species had a predominance of adults in comparison with juveniles, and a higher abundance of males than females (Tab. I). Ovigerous females were scarce and sparsely distributed along sampling periods. Each species had less than ten ovigerous individuals and no more than one per period, with the exception being L. uruguayensis, which had three of such females observed in November and four in
January. Individuals with $\mathrm{CW}<4 \mathrm{~mm}$ were observed in both subareas, with 22 found in subarea A and 17 in subarea B, all sampling periods included. Due to this low abundance, these individuals were not included in the analysis.

Spatial segregation based on the assumption of tide influence was consistent for both species, but was not registered for sex and developmental stage. Every group of L. leptodactyla was found to occupy subarea A more frequently than subarea B, whereas the opposite was found for every group of L. uruguayensis. Thus, intraspecific groups showed no spatial segregation. No interaction between space and sampling period was found, suggesting that this result was independent of seasonality. However, sampling period influenced density of juvenile females of L. leptodactyla and juvenile males of L. uruguayensis (Tab. II).

The composition of sex and developmental stage differed by subarea, and independent of period, for both L. leptodactyla (Subarea: $\mathrm{F}_{1,140}=83.550, \mathrm{p}<0.001$; Subarea*Period: $\mathrm{F}_{1,140}=1.355, \mathrm{p}=0.242$ ) and L. uruguayensis (Subarea: $\mathrm{F}_{1,140}=47.871, \mathrm{p}<0.001$; Subarea*Period: $\mathrm{F}_{1,140}=$ $1.063, \mathrm{p}=0.354)$. This result is reinforced by the NMDS ordination results, showing that areas were dissimilar in regards to group composition (Fig. 2). Sites from subarea A (upper level) were closely related based on the high density of L. leptodactyla groups. In contrast, sites from subarea B (lower level) were similar based on the high density of $L$.

Tab. I. Results from allometric growth analysis, with carapace width (CW) x propodus length (PL) for males and carapace width (CW) $\mathrm{x}$ abdomen length (AL) for females. Groups are coded as follows: J, Juveniles; A, Adults; U, Leptuca uruguayensis (Nobili, 1901); L, Leptuca leptodactyla (Rathbun in Rankin, 1898); M, males; F, females.

\begin{tabular}{|c|c|c|c|c|c|}
\hline Relationship & Group & $\mathrm{N}$ & Equation $\mathrm{Y}=\mathrm{a} \mathrm{X}^{\mathrm{b}}$ & $\mathrm{r}^{2}$ & $\begin{array}{l}\text { Size at onset of } \\
\text { sexual maturity }\end{array}$ \\
\hline \multirow{4}{*}{ CW x PL } & JUM & 112 & $\mathrm{PL}=0.104 \mathrm{CW}^{2.286}$ & 0.685 & \multirow[t]{2}{*}{$7.6 \mathrm{~mm}$} \\
\hline & AUM & 197 & $\mathrm{PL}=0.533 \mathrm{CW}^{1.514}$ & 0.712 & \\
\hline & JLM & 60 & $\mathrm{PL}=0.176 \mathrm{CW}^{2.038}$ & 0.863 & \multirow[t]{2}{*}{$7.3 \mathrm{~mm}$} \\
\hline & ALM & 288 & $\mathrm{PL}=0.769 \mathrm{CW}^{1.396}$ & 0.702 & \\
\hline \multirow{4}{*}{$\mathrm{CW} \times \mathrm{AL}$} & JUF & 40 & $\mathrm{AL}=0.126 \mathrm{CW}^{1.667}$ & 0.821 & \multirow[t]{2}{*}{$6.7 \mathrm{~mm}$} \\
\hline & AUF & 128 & $\mathrm{AL}=0.471 \mathrm{CW}^{1.396}$ & 0.737 & \\
\hline & JLF & 45 & $\mathrm{AL}=0.153 \mathrm{CW}^{1.541}$ & 0.587 & \multirow[t]{2}{*}{$6.7 \mathrm{~mm}$} \\
\hline & ALF & 211 & $\mathrm{AL}=0.443 \mathrm{CW}^{1.075}$ & 0.796 & \\
\hline
\end{tabular}

Tab. II. Mean density (ind./0.25 $\mathrm{m}^{2}$ ) of groups of L. uruguayensis and L. leptodactyla in each subarea. Results from spatial segregation analysis for each group are also given. Deviance statistics values are shown, but significance is obtained by means of chi-square test for Poisson distribution, and F-test for quasi-Poisson distribution. (*) denotes statistical significance ( $\mathrm{p}<0.05$ ). J, juveniles; A, adults; L, L. leptodactyla individuals; U, L. uruguayensis individuals; M, male; F, females; Mean \pm SD; d.f., degrees of freedom; P, Poisson; QP, Quasi-Poisson.

\begin{tabular}{|c|c|c|c|c|c|c|c|c|c|}
\hline & & JLM & JLF & ALM & ALF & JUM & JUF & AUM & AUF \\
\hline \multicolumn{10}{|l|}{$\begin{array}{l}\text { Mean density } \\
\text { (ind } / 0.25 \mathrm{~m}^{2} \text { ) }\end{array}$} \\
\hline Subarea A & & $0.65 \pm 0.16$ & $0.58 \pm 0.21$ & $3.57 \pm 0.15$ & $2.22 \pm 0.15$ & $0.46 \pm 0.18$ & $0.18 \pm 0.13$ & $0.61 \pm 0.17$ & $0.30 \pm 0.14$ \\
\hline \multirow[t]{2}{*}{ Subarea B } & & $0.19 \pm 0.14$ & $0.03 \pm 0.12$ & $0.48 \pm 0.17$ & $0.53 \pm 0.13$ & $1.11 \pm 0.14$ & $0.26 \pm 0.12$ & $2.08 \pm 0.15$ & $1.58 \pm 0.12$ \\
\hline & d.f. & & & & & & & & \\
\hline Overdisper Test & & -2.019 & -1.855 & $1.841 *$ & -1.345 & -1.204 & -1.036 & 1.188 & -2.610 \\
\hline Distribution & & $\mathrm{P}$ & $\mathrm{P}$ & QP & $\mathrm{P}$ & $\mathrm{P}$ & $\mathrm{P}$ & $\mathrm{P}$ & $\mathrm{P}$ \\
\hline Subarea & 1 & $10.374^{*}$ & $33.797 *$ & $131.077 *$ & $48.920 *$ & $36.625^{*}$ & $9.143 *$ & $97.015^{*}$ & $98.514^{*}$ \\
\hline Month & 11 & 8.300 & $21.892 *$ & 16.491 & 12.544 & $20.931 *$ & 13.617 & 13.842 & 5.442 \\
\hline Subarea:Month & 11 & 10.704 & 5.924 & 14.666 & 10.791 & 14.755 & 13.355 & 11.012 & 12.428 \\
\hline
\end{tabular}




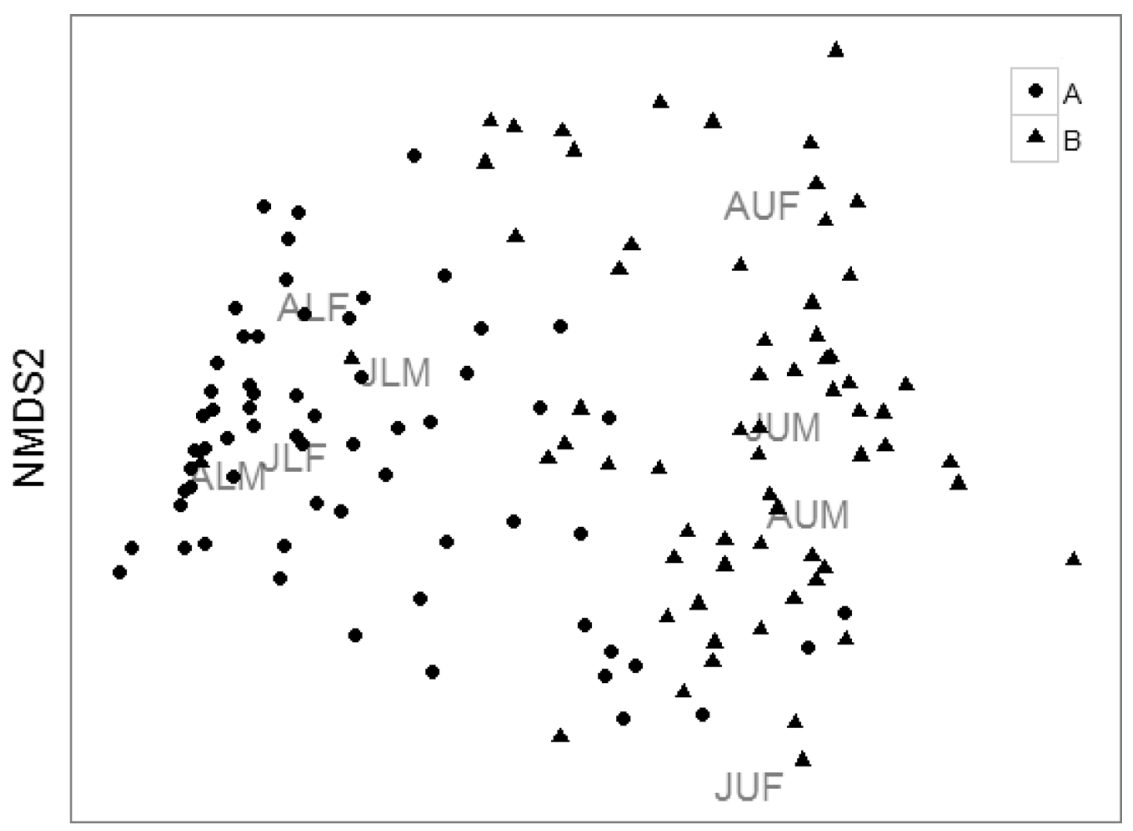

\section{NMDS1}

Fig. 2. NMDS ordination (stress $=0.16$ ) of sites based on similarity of group composition. Leptuca leptodactyla (Rathbun in Rankin, 1898): JLM (juvenile males), JLF (juvenile females), ALM (adult males) and ALF (adult females). Leptuca uruguayensis (Nobili, 1901): JUM (juvenile males), JUF (juvenile females), AUM (adult males) and AUF (adult females).

uruguayensis groups. However, sites from subarea B were less similar than sites within subarea A (Fig. 2). Similarity among sites from different subareas was low, highlighting a possible interspecific segregation found.

\section{DISCUSSION}

Large-scale studies are important to understand distribution limits, dispersion and environmental tolerance (Thurman, 1987; Thurman et al., 2013; Wieman et al., 2014). In turn, small-scale studies increase our perception of environmental heterogeneity (LEVIN, 1992) and can give better insights into realized distributions, microhabitat conditions and species interaction (MENGE \& OLSON, 1990; UNDERWOOD \& Chapman, 1996; Alves et al., 2013). Our results show that fiddler crab segregation may occur at scales smaller than those commonly researched. Leptuca leptodactyla and $L$. uruguayensis have previously been recorded as inhabiting the same habitat and with relatively high overlap (CRANE, 1975; Thurman et al., 2013; Checon \& Costa, 2017). Our results show that these species may segregate at very small scales, even without a clear granulometric gradient (both subareas classified as very fine sands), variable known to segregate these species (CHECON \& COSTA 2017). Many fiddler crab studies do not take this local spatial variability into consideration and evaluate distribution in regards to environmental variables and/or among areas with contrasting characteristics (Colpo \& Negreiros-Fransozo, 2004; BeZerra et al., 2006; BenetTI et al., 2007). This is not a problem in itself, as there is no "correct" scale to study a population or community (LEVIN, 1992), but we suggest that further distribution studies consider tidal levels to better evaluate the distribution of these organisms at different scales.

Granted, interspecific zonation at the intertidal level was previously recorded for fiddler crab species (RINGOLD, 1979; Thurman, 1987; КосH et al., 2005); however, these studies were conducted in larger (КосH et al., 2005) or heterogeneous areas, with features such as presence of mud and sand, presence/absence of vegetation or differential salinity ranges (Thurman, 1987). Our results show that commonly overlapping species can segregate at very small distances in an apparently homogeneous sedimentary environment. Thus, tidal levels should be considered even when a sedimentary gradient, which is commonly used to infer fiddler crab distribution, is not readily obvious.

Leptuca leptodactyla are known to occupy areas without vegetation cover, likely due to limitations of display visibility, as this species employs visual cues for reproduction such as sand-hoods built at the burrow entrance (CHRISTY et al., 2002; MASUNARI, 2012; RODRIGUES et al., 2016). Leptuca leptodactyla distribution is also found to be negatively correlated with organic matter content and soil moisture (Bezerra et al., 2006). In regards to organic matter, no difference was found between subareas, but humidity may be a reason for the low occurrence of $L$. leptodactyla in subarea B. Although humidity was not directly measured, subarea B was closer to the tideline and spent more time submerged during high tide. Areas with higher humidity, i.e. lower tidal levels, have less variability in temperature with tide variation. High temperature is an important stressful factor 
for intertidal organisms, especially smaller ones like fiddler crabs (Thurman, 1998; Allen et al., 2012). Physiological changes resulting in mortality may occur to crabs exposed to such temperatures, due to desiccation. Species may also have different tolerance limits for high temperatures (THURMAN, 1998; Rabalais \& CAMERON, 2001). Although desiccation resistance is still to be studied in either species, it is possible that $L$. leptodactyla are more resilient or show an adaptive behavior (e.g. more time spent within burrows) for living in areas with low soil moisture, as has been shown in fiddler crabs inhabiting dry environments (RABALAIS \& CAMERON, 2001). Thus, limiting exposure to this stressful condition is an important component affecting fiddler crab distribution.

Leptuca uruguayensis is one of the fiddler crab species in which a burrow plugging behavior has been described, with individuals closing the burrow as it is inundated (DE LA IGLeSIA et al., 1994). This behavior avoids burrow collapse and enhances respiration by maintaining an air column within the burrow during high tide (DE LA IGLESIA et al., 1994), enabling the occurrence of this species in lower intertidal areas, where desiccation stress is lower. While burrow plugging has not being described in L. leptodactyla, adaptations for occupation of lower levels do not justify the low density of L. uruguayensis at the upper levels. An explanation may lie on sediment properties: although the subareas did not vary in regards to mean grain diameter, existence of particular sediment fractions may also influence species occurrence (MOHKTARI et al., 2015).

Fiddler crabs possess feeding appendage (second maxilliped) adaptations which are related to sediment properties. Spoon-tipped setae are modified to extract organic matter from coarser sands; whereas plumosae setae are more suitable for finer sands (Colpo \& Negreiros-Fransozo, 2013). Leptuca leptodactyla is the Brazilian species with most spoon-tipped setae, lacking plumosae setae in the second maxiliped, which makes it unsuitable for extracting organic matter from very fine grains (COSTA \& NEGREIROSFransozo, 2001; Bezerra et al., 2006). Subarea B had a higher content of silt/clay fractions, which could limit the occurrence of L. leptodactyla at the lower level. Conversely, L. uruguayensis have a mixed presence of plumosae and spoon-tipped setae (COSTA \& NEGREIROS-Fransozo, 2001; THURMAn et al., 2013), making them more suitable for occupying subarea $\mathrm{B}$. When considering the c-index, a metric based on maxilliped and carapace length and width, $L$. leptodactyla and L. uruguayensis share a similar classification (c-index $>90$, species which feed on coarse sands) (THuRman et al., 2013). Thus, if silt/clay fractions are to be considered responsible for the observed segregation, this index does not seem appropriate for predicting patterns at small scales. However, our design is limited in defining the usefulness of the c-index, and future studies should focus on testing the significance on understading fiddler crab distribution.

The role that competition may play on generating the observed patterns also cannot be discarded. Competitive interactions in fiddler crabs may limit the distribution of a given species (RINGOLD, 1979; Frith \& BRUNENMEISTER,
1980; NobBs, 2003). Evidences of direct antagonistic interactions between fiddler crab species exist, but these interactions are conditioned by density-dependant processes and recognition of familiarity (KNELL, 2009; SANTOS et al., 2015, 2018). Although this competitive interference may be happening, our results are limited to address the extent to which competition plays a role in segregation. This can be investigated in the future by manipulative exclusion studies, although they may be difficult to apply in situ due to fiddler crab abundance, motility and burrowing behavior.

Intraspecific small-scale segregation has not been recorded for either species, irrespective of sex or developmental stage, as every group of L. leptodactyla and L. uruguayensis were registered in the upper and lower subarea, respectively. Patterns of intraspecific segregation were previously registered for fiddler crabs: females and smaller males of Uca vocans prefer to burrow at lower intertidal levels, whereas larger males burrow at the upper levels (Murai et al., 1983). Similarly, L. leptodactyla juveniles (minimum $\mathrm{CW}>4 \mathrm{~mm}$ ) were previously found to be more abundant at lower levels, with adults occupying the area with no regards to tidal level (R. Cardoso, unpubl. data). However, in both cases, species had no congeneric organisms sharing the habitat. Fiddler crab larvae from different species tend to settle at similar intertidal levels as their conspecific adults (O'CONNOR, 1993), while further evidence suggests that settlement and metamorphic molting depend on cues given by the presence of conspecific adults on the sediment (O'CONNOR \& VAN, 2006; SiмiтH et al., 2010). That seems in accordance with our results, as juveniles and adults of both species did not show patterns of small-scale segregation according to tide level. Individuals smaller than $4 \mathrm{~mm}$ were recorded in both subareas and, given the preference for settlement in the presence of adults, it is likely they belong to the same dominant species in each subarea considering what is known in literature. The observed spatial segregation was also independent of seasonality. Although the monthly interval did not allow us to infer the effects of small temporal processes such as storms or wind surges, events of larger time scales such as reproduction and recruitment did not seem to influence this pattern. Few ovigerous females were sampled, which hinders assumptions regarding reproductive period, but $L$. leptodactyla has been suggested to have continuous reproduction (BEZERRA et al., 2006), whereas L. uruguayensis may reproduce either in peaks (SPIVAK et al., 1991) or continuously (CosTA et al., 2006). Nonetheless, even if those species do present peaks of reproduction, breeding season did not seem to influence spatial segregation.

The present study highlights the importance of considering the segregation that species might exhibit at small scales, even when no environmental gradient is readily apparent. Although L. leptodactyla and L. uruguayensis overlap in their occurrence if no intertidal zonation is considered, they segregate when tide levels are individually sampled as microhabitats. Tidal level seems to be an important factor affecting fiddler crab local distribution, likely due to contrasting times of submersion, and consequent humidity 
content. Therefore, it is important to consider in studies of macrobenthic distribution. Silt/clay fractions may also play a role due to the relationship with mouth appendages. Lastly, competition cannot be discarded, but experimental studies are required to consistently infer effects arising from interspecific interaction.

Acknowledgements. The authors would like to thank Dr. Glauco de Oliveira Barreto Machado and Dr. João Bosco Leite GusmãoJúnior for their support during sampling activities and parameter analysis. We thank the Coordenação de Aperfeiçoamento de Pessoal do Ensino Superior (Capes) for grants to HHC. We would also like to acknowledge the Universidade Estadual Paulista - Campus do Litoral Paulista for providing structural support.

\section{REFERENCES}

Allen, B. J.; Rodgers, B.; Tuan, Y. \& Levinton, J. S. 2012. Sizedependent temperature and desiccation constraints on performance capacity: Implications for sexual selection in a fiddler crab. Journal of Experimental Marine Biology and Ecology 538:93-99.

Alves, J. A.; Gunnarson, T. G.; Potts, P. M.; Sutherland, W. J. \& Gill, J. A. 2013. Sex-biases in distribution and resource use at different spatial scales in a migratory shorebird. Ecology and Evolution 3(4): 1079-1090.

ANDERSON, M. J. 2001. A new method for non-parametric multivariate analysis of variance. Austral Ecology 26:32-46.

Baltz, D. M. \& Moyle, P. B. 1984. Segregation by species and size classes of rainbow trout, Salmo gairdneri, and Sacramento sucker, Catosomus occidentalis, in three California streams. Environmental Biology of Fishes 10(1):101-110.

Benetti, A. S.; Negreiros-Fransozo, M. L. \& Costa, T. M. 2007. Population and reproductive biology of the crab Uca burgersi (Crustacea: Ocypodidae) in three subtropical mangrove forests. Revista de Biologia Tropical 55(1):55-70.

Bezerra, L. E. A. 2012. The fiddler crabs (Crustacea: Brachyura: Ocypodidae: genus $U c a$ ) of the South Atlantic Ocean. Nauplius 20(2):203-246.

Bezerra, L. E. A.; Dias, C. B.; Santana, G. X. \& Matthews-Cascon, H. 2006. Spatial distribution of fiddler crabs (genus $U c a$ ) in a tropical mangrove of northeast Brazil. Scientia Marina 70(4):759-766.

Bogazzi, E.; Iribarne, O. O.; Guerrero, R. \& Spivac, E. D. 2001. Wind pattern may explain the southern limit of distribution of a southwestern Atlantic fiddler crab. Journal of Shellfish Research 20(1):353-360.

Borcard, D.; Gillet, F. \& Legendre, P. 2011. Numerical ecology with R. New York, Springer-Verlag. 319p.

BRAY, J. R. \& CURTIS, J. T. 1957. An ordination of the upland forest communities of Southern Winscosin. Ecological Monographs 27:325-349.

Checon, H. H. \& Costa, T. M. 2017. Fiddler crab (Crustacea: Ocypodidae) distribution and the relationship between habitat occupancy and mouth appendages. Marine Biology Research 14:1-12.

Christy, J. C.; Backwell, P. Y. R.; Goshima, S. \& Kreuter, T. 2002. Sexual selection for structure building by courting male fiddler crabs: an experimental study of behavioral mechanisms. Behavioral Ecology 13(3):366-374.

Clarke, K. R. 1993. Non-parametric multivariate analysis of changes in community structure. Australian Journal of Ecology 18:117-143.

Clarke, K. R.; Somerfield, P. J. \& Chapman, M. G. 2006. On resemblance measures for ecological studies, including taxonomic dissimilarities and zero-adjusted Bray-Curtis coefficient for denuded assemblages. Journal of Experimental Marine Biology and Ecology 330:55-80.

Colpo, K. D. \& Negreiros-Fransozo, M. L. 2004. Comparison of the population structure of the fiddler crab Uca vocator (Herbst, 1804) from three subtropical mangrove forests. Scientia Marina 64(1):139-146.

Colpo, K. D. \& Negreiros-Fransozo, M. L. 2013. Morphological diversity of setae on the second maxilliped of fiddler crabs (Decapoda: Ocypodidae) from the southwestern Atlantic Coast. Invertebrate Biology 132(1):38-45.

Costa, T. M. \& Negreiros-Fransozo, M. L. 2001. Morphological adaptation of the second maxilliped in semiterrestrial crabs of the genus Uca Leach 1814 (Decapoda, Ocypodidae) from a subtropical Brazilian mangrove. Nauplius 9(2):123-131.

Costa, T. M.; Silva, S. M. J. \& Negreiros-Fransozo, M. L. 2006. Reproductive pattern comparison of Uca thayeri Rathbun, 1900 and Uca uruguayensis Nobili, 1901 (Crustacea, Decapoda, Ocypodidae). Brazilian Archives of Biology and Technology 49(1):117-123.

Crane, J. 1975. Fiddler crabs of the world (Ocypodidae: Genus $\boldsymbol{U} \boldsymbol{c a}$ ). Princeton, Princeton University Press. 736p.

De La Iglesia, H.; Rodriguez, M. E. \& Dezi, R. E. 1994. Burrow plugging in the fiddler crab Uca uruguayensis and its synchronization with two environmental cycles. Physiology and Behavior 55(5):913-919.

FAITH, D. P.; Minchin, P. R. \& Belbin, L. 1987. Compositional dissimilarity as a robust measure of ecological distance. Vegetatio 69:57-68.

FoLK, R. L. \& WARD, W. C. 1957. Brazos River Bar: a study in the significance of grain-size parameters. Journal of Sedimentary Petrololy 27(1):3-26.

Frith, D. W. \& BRUNENMEISTER, S. 1980. Ecological and population studies of fiddler crabs (Ocypodidae: Genus $U c a$ ) on a mangrove shore at Phuket Island, western peninsular Thailand. Crustaceana 39(2):157-184.

GotelLI, N. J. \& MCCABE, D. J. 2002. Species co-occurrence: a meta-analysis of J.M. Diamond's assembly rules model. Ecology 83(8):2091-2096.

Green, J. L. \& PlotKin, J. B. 2007. A statistical theory for sampling species abundance. Ecology Letters 10:1037-1045.

HarTNOLL, R. G. 1978. The determination of relative growth in Crustacea. Crustaceana 34(3):281-293.

Hewitt, J. E.; Thrush, S. F.; Halliday, J. \& Duffy, C. 2005. The importance of small-scale habitat structure for maintaining beta diversity. Ecology 86(6): 1619-1626.

Hirose, G. L.; Fransozo, V.; Tropea, C.; López-Greco, L. S. \& NegreirosFransozo, M. L. 2013. Comparison of body size, relative growth and size at onset of sexual maturity of Uca uruguayensis (Crustacea: Decapoda: Ocypodidae) from different latitudes in the south-western Atlantic. Journal of the Marine Biological Association of the United Kingdom 93(3):781-788.

Horner-Devine, M. C.; Silver, J. M.; Leibold, M. A.; Bohannan, B. J.; Colwell, R. K.; Fuhrman, J. A.; Green, J. L.; KusKe, C. R.; MartinY, J. B.; Muyzer, G.; Ovre̊̊s, L.; Reysenbach, A. L. \& Smith, V. H. 2007. A comparison of taxon co-occurrence patterns for macro- and microorganisms. Ecology 88(6):1345-1353.

JAIN, A. K. 2010. Data clustering: 50 years beyond K-means. Pattern Recognition Letters 31:651-666.

KLeIBER, C. \& ZeILeIs, A. 2008. Applied echonometrics with R. Available at $<$ http://cran.r-project.org/package $=$ AER $>$.

KNELL, R. J. 2009. Population density and the evolution of male aggression. Journal of Zoology 278:83-90.

Koch, V.; WolfF, M. \& Diele, K. 2005. Comparative population dynamics of four fiddler crabs (Ocypodidae, genus Uca) from a North Brazilian mangrove ecosystem. Marine Ecology Progress Series 292(1):177-188.

KRUSKAL, J. B. 1964. Multidimensional scaling by optimizing goodness of fit to a nonmetric hypothesis. Psychometrika 29:1-27.

LEVIN, S. A. 1992. The problem of pattern and scale in ecology: the Robert H. MacArthur award lecture. Ecology 73(6):1943-1967.

MACHADO, G. B. O.; GuSMÃo-JúNIOR, J. B. L. \& Costa, T. M. 2013. Burrow morphology of Uca uruguayensis and Uca leptodactylus (Decapoda: Ocypodidae) from a subtropical mangrove forest in the western Atlantic. Integrative Zoology 8:307-314.

MASUNARI, S. 2012. Hood construction as an indication of the breeding period of the fiddler crab Uca (Leptuca) leptodactyla Rathbun 1898 (Decapoda, Ocypodidae) from Guaratuba Bay, southern Brazil. Crustaceana 85(10):1153-1169.

Masunari, S. \& SWIEch-Ayoub, B. P. 2003. Crescimento relativo em Uca leptodactyla Rathbun (Crustacea Decapoda Ocypodidae). Revista Brasileira de Zoologia 20(3):487-491.

Melo, G. A. S. 1996. Manual de identificação dos Brachyura (caranguejos e siris) do litoral brasileiro. São Paulo, Editora Plêiade. 604p.

Menge, B. A. \& Olson, A. M. 1990. Role of scale and environmental factors in regulation of community structure. Trends in Ecology and Evolution 5(2):52-56.

Mohktari, M.; Ghaffar, M. A.; Usup, G. \& CoB, Z. C. 2015. Determination of key environmental factors responsible for distribution patterns of fiddler crabs in a tropical mangrove system. PlosOne 10(1):1-17. 
Murai, M.; Goshima, S. \& NaKasone, Y. 1983. Adaptative droving behavior observed in the fiddler crab Uca vocans vocans. Marine Biology 76(1):159-164.

Nabout, J. C.; Marco Júnior, P.; Bini, L. M. \& Diniz-Filho, J. A. F. 2009. Distribuição geográfica potencial de espécies americanas do caranguejo-violinista (Uca spp.) (Crustacea, Decapoda) com base em modelagem de nicho ecológico. Iheringia, Série Zoologia 99(1):92-98.

Natalio, L. F.; Pardo, J. C. F.; Machado, G. B. O.; Fortuna, M. D.; Gallo, D. G. \& Costa, T. M. 2017. Potential effect of fiddler crabs on organic matter distribution: A combined laboratory and field experimental approach. Estuarine, Coastal and Shelf Science 184:158-165.

Negreiros-Fransozo, M. L.; Colpo, K. D. \& Costa, T. M. 2003. Allometric growth in the fiddler crab Uca thayeri (Brachyura, Ocypodidae) from a subtropical mangrove. Journal of Crustacean Biology 23(2):273-279.

NoBbs, M. 2003. Effects of vegetation differ among three species of fiddler crabs (Uca spp.). Journal of Experimental Marine Biology and Ecology 284(1):41-50.

O'CONNOR, N. J. 1993. Settlement and recruitment of the fiddler crabs Uca pugnax and $U$. pugilator in a North Carolina, USA, salt marsh. Marine Ecology Progress Series 93(1):227-234.

O’CONNOR, N. J. \& VAN, B. T. 2006. Adult fiddler crabs Uca pugnax (Smith) enhance sediment-associated cues for molting of conspecific megalopae. Journal of Experimental Marine Biology and Ecology 335(1):123-130.

O'HarA, R. B. \& Kotze, D. J. 2010. Do not log-transform count data. Methods in Ecology and Evolution 1(2):118-122.

Oksanen, J.; Blanchet, F. G.; Friendly, M.; Kindt, R.; Legendre, P.; McGlinn, D.; Minchin, P. R.; O’Hara, R. B.; Simpson, G. L.; Solymos, P.; Stevens, M. H. H.; Szoecs, E. \& Wagner, H. 2013. vegan: Community Ecology Package. Available at $<$ https://cran.r-project.org/ $>$.

R Core Team. 2013. R: A language and environment for statistical computing. Available at $<$ http://www.r-project.org $>$.

Rabalais, N. N. \& Cameron, J. N. 2001. Physiological and morphological adaptations of adult Uca subcylindrica to semi-arid environments. Biological Bulletin 168:135-146.

RINGOLD, P. 1979. Burrowing, root mat density, and the distribution of fiddler crabs in the eastern United States. Journal of Experimental Marine Biology and Ecology 36(1):11-21.

Rosenberg, M. S. 2001. The systematics and taxonomy of fiddler crabs: a phylogeny of the genus Uca. Journal of Crustacean Biology 21(3):839-869

Rodrigues, R. O.; Costa, T. M. \& Barreto, R. E. 2016. Burrow ornamentation in fiddler crab (Uca leptodactyla): female mate choice and male-male competition. Marine and Freshwater Behavior and Physiology 49:317-325.

Sampedro, M. P.; González-Gurriaran, E.; Freire, J. \& Muiño, R. 1999. Morphometry and sexual maturity in the spider crab Maja squinado (Decapoda: Majidae) in Galicia, Spain. Journal of Crustacean Biology 19(3):578-592.
Sanches, F. H. C.; Costa, T. M.; Barreto, R. E. \& Backwell, P. Y. R. 2018 The cost of living in mixed species population: a fiddler crab example. Journal of Experimental Marine Biology and Ecology 500:30-33.

Santos, L. C.; Alencar, C. E. R. D.; Freire, F. A. M. \& Luchiari, A. C. 2015. Agonistic interactions in the male fiddler crab Uca leptodactyla Rathbun, 1898 at varying scales. Crustaceana 66(8):625-640.

Shih, H-T.; NG, P. K. L.; Davie, P. J. F.; Schubart, C. D.; Türkay, M.; Naderloo, R.; Jones, D. \& LiU, M-Y. 2016. Systematics of the family Ocypodidae Rafinesque 1815 (Crustacea: Brachyura), based on phylogenetic relationships, with a reorganization of subfamily rankings and a review of the taxonomic status of $U c a$ Leach, 1814, sensu lato and its subgenera. Raffles Bulletin of Zoology 64 (1):139-175.

Simith, D. J. B.; Diele, K. \& Abrunhosa, F. A. 2010. Influence of natural settlement cues on the metamorphosis of fiddler crab megalopae, $U \mathrm{ca}$ vocator (Decapoda: Ocypodidae). Anais da Academia Brasileira de Ciências 82(2):313-321

SpivaK, E. D.; Gavio, M. A. \& Navarro, C. E. 1991. Life history and structure of the world's southernmost Uca population: Uca uruguayensis (Crustacea, Brachyura) in Mar Chiquita Lagoon (Argentina). Bulletin of Marine Science 48(3):679-688.

Thrush, S. F.; Hewitt, J. E \& Pridmore, R. D. 1989. Patterns in the spatial arrangement of polychaetes and bivalves in intertidal sands. Marine Biology 102(4):529-535.

Thrush, S. F.; Hewitt, J. E.; Pridmore, R. D. \& Cemmings, V. J. 1996 Adult/juvenile interactions of infaunal bivalves: contrasting outcomes in different habitats. Marine Ecology Progress Series 132(1):83-92.

Thurman, C. L. 1987. Fiddler crabs (genus Uca) of eastern Mexico (Decapoda, Brachyura, Ocypodidae). Crustaceana 53(1):94-105.

Thurman, C. L. 1998. Evaporative water loss, corporal temperature and the distribution of sympatric fiddler crabs $(U c a)$ from South Texas. Comparative Biochemistry and Physiology 119(1):279-286.

Thurman, C. L.; Faria, S. C. \& McNamara, J. C. 2013. The distribution of fiddler crabs $(U c a)$ along the coast of Brazil: implications for biogeography of the western Atlantic Ocean. Marine Biodiversity Records 6(1):1-21.

Underwood, A. J. \& Chapman, M. G. 1996. Scales of spatial patterns of distribution of intertidal invertebrates. Oecologia 107(2):212-224.

Ver Hoef, J. M. \& Boveng, P. L. 2007. Quasi-poisson vs negative binomial regression: how should we model overdispersed count data? Ecology 88(11):2766-2772.

Werner, E. E. \& Gilliam, J. F. 1984. The ontogenetic niche and species interactions in size-structured populations. Annual Review of Ecological Systems 15:393-425.

Wieman, A. C.; Berendzen, P. B.; Hampton, K.; Jang, J.; Hopkins, M. J. \& Jurgenson, J. 2014. A panmictic fiddler crab from the coast of Brazil? Impact of divergent ocean currents and larval dispersal potential on genetic and morphological variation in Uca maracoani. Marine Biology 161(1):173-185.

WIENS, J. A. 1989. Spatial scaling in ecology. Functional Ecology 3(4):385-397. 